УДК 615.322:543.544+615.218.3:582.632.1

\title{
АЛЛЕРГЕННЫЙ ПРОФИЛЬ ПОЛНОГО ЭКСТРАКТА ПЫЛЬЦЫ БЕРЕЗЫ (BETULA PENDULA ROTH): ИЗУЧЕНИЕ MЕТОДОЛОГИЧЕСКИХ ПОДХОДОВ К ИДЕНТИФИКАЦИИ И КОЛИЧЕСТВЕННОМУ ОПРЕДЕЛЕНИЮ МАЖОРНОГО БЕЛКА ВЕТ V 1 МЕТОДОМ ВЭЖХ/МС/МС
}

\section{() Д.О. Боков, В.В. Смирнов*}

\author{
Первый Московский государственный медицинский университет \\ им. И.М. Сеченова, ГСП-1, ул. Трубецкая, 8, Москва, 119991, (Россия), \\ e-mail:fmmsu@mail.ru
}

\begin{abstract}
Береза повислая, Betula pendula Roth. (Betulaceae L.), издревле применяется в медицинской практике благодаря широкому спектру биологически активных соединений, присутствующих практически во всех частях растения. Однако пыльца березы является причиной тяжелых аллергических заболеваний - поллинозов. В сообщении приводятся данные, касающиеся стандартизации компонентного состава полного аллергенного экстракта пыльцы березы. Данный иммунобиологический препарат представляет собой сумму аллергенных белков (Bet v), применяется для проведения аллергенспецифической иммунотерапии (АСИТ). Поскольку в России протоколы стандартизации данного аллергенного экстракта не отвечают современным мировым требованиям, возникла необходимость в разработке чувствительной методики количественного определения главного аллергенного белка Bet v 1 с использованием современных физикохимических методов, такого как ВЭЖХ/МС/MC.

Ключевые слова: береза повислая, Betula pendula Roth., Betula verrucosa Ehrh., пыльца, аллергенный экстракт, Bet v 1, аллергенспецифическая иммунотерапия (АСИТ), поллиноз, ВЭЖХ/МС/MC.
\end{abstract}

\section{Введение}

Среди произрастающих в мире около 120 видов берез (род Betula L.) наиболее известной стала береза повислая - Betula pendula Roth., семейства Березовые - Betulaceae L., (syn.: береза бородавчатая - Betula verrucosa Ehrh.) (рис. 1) [1].

Ареал рода Береза чрезвычайно обширный - его представители произрастают практически по всему миру, за исключением Африки и Австралии [1]. В медицине довольно широко используются листья березы (Folium Betulae), березовые почки (Gemmae Betulae) и березовый сок (Succus Betulae), а также иногда кору березы (бересту - Cortex Betulae). Потенциальный интерес связан с биологически активными соединениями (БАС) березы в отходах, возникающих при заготовке древесины: листьев и почек [2]. Однако заготовка пыльцы березы в таких случаях не проводится, что, безусловно, является упущением для нашей фармацевтической промышленности [3]. В листьях обнаружены следующие группы БАС: бутиловый эфир бетулоретиновой кислоты; эпикутикулярные воска - алканы, жирные кислоты, первичные спирты и др.; витамины - аскорбиновая кислота (28\%); сапонины (до 4,1\%); флавоноиды - гиперозид, кверцитин и др.

Боков Дмитрий Олегович - студент, e-mail: fmmsu@mail.ru

Смирнов Валерий Валерьевич - старший преподаватель кафедры фармацевтической и токсикологической химии, кандидат фармацевтических наук, e-mail: vall@mail.mipt.ru (до 3,2\%); дубильные вещества (4,5-9,5\%); эфирное масло - кариофиллен, гумулен (около 0,05\%); кислоты - 4-гидрокси-бензойная, линоленовая, фенилуксусная, салициловая, ванилиновая, кумаровая, феруловая, олеаноловая. Листья используются в качестве диуретического средства [4-6].

\footnotetext{
* Автор, с которым следует вести переписку.
} 


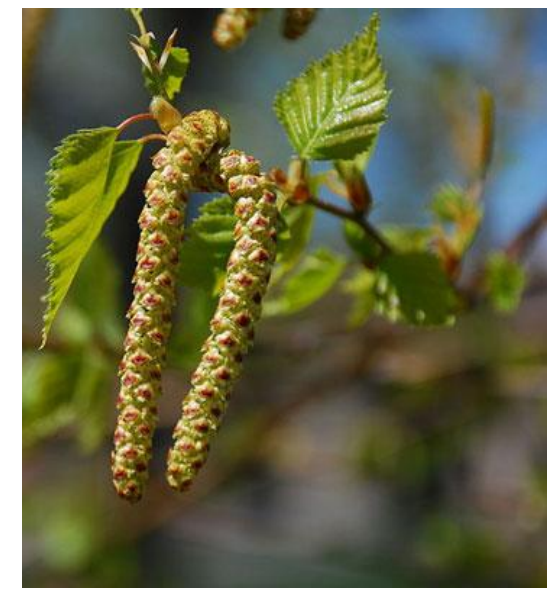

Рис. 1. Мужское соцветие березы повислой (Betula pendula Roth)

В химический состав почек березы повислой входят: флавоноиды - гиперозид, 3-дигалактозид мирицетина, производные апигенина, нарингенина (до 0,3\%) и др.; эфирное масло - кариофиллен, гумулен, бетулен, бутиловый эфир бетуленовой кислоты, сесквитерпеновый спирт бетулол (2-6\%); витамины - витамин С (до 3,2\%); дубильные вещества (до 10\%); тритерпеновые спирты - фолиентетрол, фолиентриол; ненасыщенные жирные кислоты - линолевая, линоленовая; нор-сесквитерпеновый альдегид - биркеналь; тритерпеновые соединения - даммарадиенон; кислоты - мороновая, бетулоновая, 28-ацетокси-3,4-секо-олеан$4(24), 13(18)$-диен-3-овая и др. [7-11]. Березовые почки обладают мочегонным желчегонным действием [1].

В березовом соке содержатся: витамины группы В, С, микроэлементы и минеральные соли, сапонины, сахара, бетулол, яблочная кислота, дубильные вещества, эфирные масла и ароматические вещества. В коре березы повислой содержатся: гликозиды (гаультерин и бетулозид), тритерпеновые спирты - бетуленол (бетулин) и др., фенольный комплекс - кислоты (оксибензойная, протокатехиновая, ванилиновая, сиреневая), дубильные вещества (катехины), лейкоантоцианы, эфирное масло, флавонолы, суберин. По методу сухой перегонки из бересты вырабатывают деготь, который включен в состав мазей Вилькинсона и Вишневского [1, 12].

Березовая пыльца содержит витамины А, $\mathrm{B}_{1}, \mathrm{~B}_{6}, \mathrm{E}, \mathrm{F}, \mathrm{K}$, аскорбиновую и фолиевую кислоты, микроэлементы, а также фитонциды, которые благотворно воздействуют на организм человека, обеспечивая его полноценную работу. Липофильная фракция, представленная липидами (от 32 до 52 мг/г сухого вещества), относящихся как к запасным (нейтральным) липидам (43\%), так и мембранным (24\% фосфолипидам и $33 \%$ гликолипидам) [13, 14].

Поллинозы, или пыльцевые аллергии, (от лат. pollen - пыльца) сами по себе представляют хронические сезонные воспалительные аллергические заболевания, причиной которых является пыльца различных растений. Клинически подобные заболевания проявляются в виде сезонных аллергических конъюнктивитов и ринитов, которые часто сопровождаются развитием более тяжелых заболеваний, таких как бронхиальная астма, а также другими симптоматическими проявлениями [15]. Поллинозы представляют глобальную медико-социальную нерешенную проблему из-за широкого распространения, высокого риска развития дополнительных осложнений, выраженного снижения общей работоспособности и качества жизни самих пациентов [16].

Аллергены пыльцы представляют самую большую группу неинфекционных аллергенов, именно они становятся этиологическим фактором развития аллергических

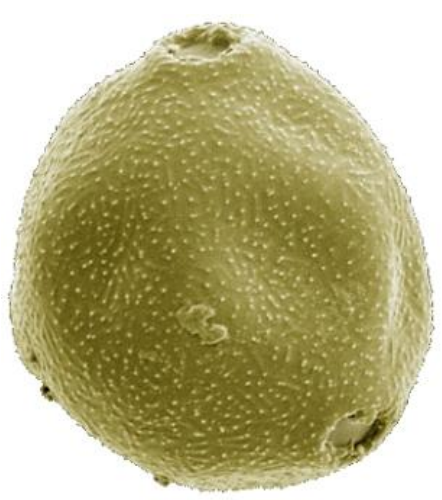

Рис. 2. Пыльцевое зерно березы повислой (Betula pendula Roth) растровая электронная микроскопия (SEM) конъюнктивитов и ринитов. Известно великое множество подобных аллергенных растений, наибольшую опасность в этом плане представляют растения рода Береза (Betula L.). Однако для различных областей характерен свой сезонный календарь, когда в атмосферном воздухе преобладает пыльца определенного растения, преобладающего на данной территории. С целью систематизации данных составляются «флористические карты» и подробный список растений, образующих аллергенную пыльцу в областях и краях [17]. Так, в центральной полосе Российской Федерации поллинозы наиболее часто связаны с сенсибилизацией к пыльце березы (рис. 2), ольхи, орешника [18, 19].

Береза повислая цветет ранней весной (апрель - май) до раскрытия листьев. Пыльца образуется в больших количествах, она легко распространяется ветром, становясь причиной заболевания поллинозом среди населения. Согласно исследованию, проведенному в Москве, методом обратного ИФА с применени- 
ем поликлональных антисывороток при исследовании 78 образцов пыли из квартир было установлено, что концентрации аллергенов пыльцы березы у 42 образцов составляли более 300 мкг/г пыли, а у остальных образцов - около 166 мкг/г пыли. Таким образом, подобные естественные высокие экспозиции аллергена в окружающей среде становятся причиной обострения поллиноза [20].

Аллергенспецифическая иммунотерапия (АСИТ) - Allergen-specific immunotherapy (SIT) - всегда занимала особое место среди методов лечения аллергических заболеваний [18]. Для проведения АСИТ чаще всего используются так называемые водно-солевые экстракты аллергенов, ответственных за возникновение заболевания, а также аналогичные биологические препараты $[3,15,16]$. Поскольку лечебные и диагностические аллергены изготавливаются из натурального сырья, в частности сбор пыльцы березы проводится в естественных условиях, состав данных лекарственных препаратов может в значительной степени варьироваться $[15,21]$.

Экстракт пыльцы березы - сложный по составу комплекс соединений, полученный путем дефрагментации и последующего извлечения из сырья смеси белков, который содержит определенную группу аллергенов, гликолипидов, гликопротеидов и других сопутствующих компонентов [3]. Следует отметить, что главным (мажорным) аллергеном, на который приходится до 95\% всей аллергенной специфической активности экстракта, является белок Bet v 1 (рис. 3), входящий в суперсемейство PR-10 (Superfamily of pathogenesis-related proteins), являющийся гликопротеином по строению (20\% углеводных остатков) с молекулярной массой 17 кД [3, 21]. Присутствие белков суперсемейства PR-10 возможно определить в большом количестве природных источников, как, например, пыльца березы и лещины, морковь, яблоко, персик, арахис, киви, соя, сельдерей. Благодаря достаточно высокой гомологичности белковых структур возникает проявление значительного иммуногенного сходства. Данный факт является частой причиной возникновения нежелательной иммунологической аллергенной перекрестной реактивности.

Другой Аллерген Bet v 2 ответственен за кросс-реактивность между рядом ботанически неродственных деревьев и кустарников (ольха, береза, тополь, оливковое дерево, вяз, платан, дуб, конский каштан, клен), а также пыльцы березы с некоторым набором растительных продуктов (морковь, лесные орехи, картофель, сельдерей, томаты), его специфическая активность вместе с остальными белками составляет около 5\%, что не влияет на структуру заболевания поллинозом [23].

Для того чтобы аллергенные экстракты имели эквивалентный антигенный состав и специфическую активность, требуется процедура стандартизации $[3,15,21]$. Поскольку самый большой вклад в формирование аллергической реакции вносит белок Bet v 1, наиболее целесообразно проводить стандартизацию экстракта пыльцы березы повислой по этому аллергенному белку. Концентрацию белка Bet v 1 возможно определить методом высокоэффективной жидкостной хроматографии с тандемной масс-спектрометрией (ВЭЖХ/MC/MC) - high-performance liquid chromatography-tandem mass spectrometry (HPLC/MS/MS). Cегодня данное направление является приоритетным в области стандартизации аллергенных экстрактов [3].

Таким образом, в цели и задачи данного исследования входили: определение оптимального параметра, относительно которого будет проводиться стандартизация аллергенного экстракта, что невозможно без изучения химического состава, а также разработка и валидация методики стандартизации данного экстракта по выбранному компоненту с использованием метода HPLC/MS/MS.

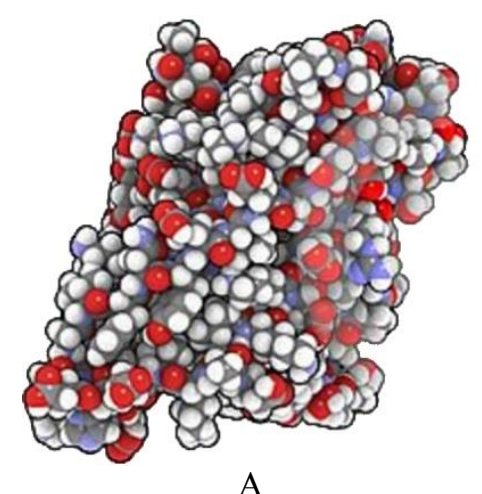

A

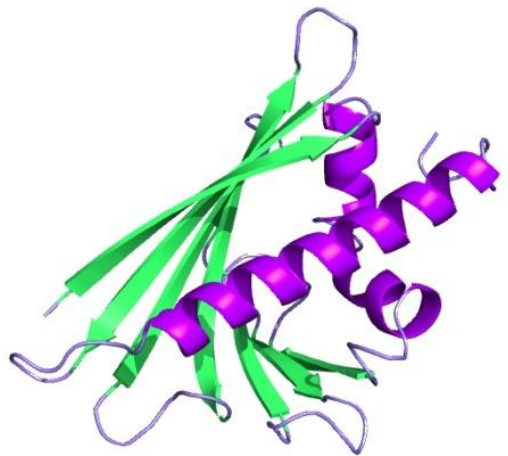

Б

Рис. 3. Структурные модели белка Bet v 1 


\section{Экспериментальная часть}

В качестве объекта исследования выступал полный экстракт пыльцы березы повислой (Betula pendula Roth). Сырьевые материалы были получены в 2012 г. в период с 25 апреля по 14 мая: соцветия с пыльцой собирались в лесопарковых зонах Москвы и Московской области со свисавших ветвей деревьев, без наличия видимых повреждений вредителями и грибковыми заболеваниями, диаметром стволов 20 35 см. Сушка воздушно-теневая при температуре не выше $35^{\circ} \mathrm{C}$. Высушенное сырье хранилось в герметично укупоренных емкостях в сухом помещении.

Полный экстракт пыльцы березы получали стандартным способом для аллергенных экстрактов, где в качестве сырья используется пыльца растений, по методу Кока [24] без модификаций. Далее полученный экстракт подвергали лиофильной сушке.

Методика проведения анализа экстракта включала следующие этапы: подготовку хроматографической системы к анализу, пробоподготовки объектов исследования, приготовление подвижной фазы, и непосредственное проведение ВЭЖХ-анализа с последующим тандемным хромато-масс-селективным детектированием.

Подготовка хроматографической системы к анализу включала в себя подготовку компонентов подвижной фазы (проверку и коррекцию $\mathrm{pH}$, фильтрование, при необходимости); смену компонентов подвижной фазы, промывку каналов подачи и насосов; уравновешивание хроматографической системы: промывание колонки исходным составом подвижной фазы при включенном термостате и детекторе до тех пор, пока базовая линия не выйдет на определенный постоянный уровень (не менее 10 колоночных объемов); проверку пригодности хроматографической системы к работе: соответствие общих параметров работы прибора (давление, изменение сигнала детектора во времени, уровень шума).

Пробоподготовка включала в себя следующие этапы: экстракт пыльцы березы (точную навеску около 10 мг) помещали в мерную колбу объемом 100 мл, растворяли в воде деионизированной и доводили объем до метки тем же растворителем. 2 мл полученного раствора пропускали через фильтр с размером пор 0,4 мкм. Фильтрат помещали во флакон для хроматографирования объемом 2 мл.

Далее полученный раствор с определяемым белком Bet v 1 анализировали методом ВЭЖХ. При анализе использовался жидкостной хроматограф SHIMADZU (Япония) с тандемным масс-селективным детектором (Япония). Условия хроматографирования подбирались экспериментальным путем: в качестве подвижной фазы использовали смесь $0,1 \%$ раствора муравьиной кислоты в воде с ацетонитрилом (55:45); колонка: Agilent XDB-C18 4,6×150 мм; 5,0 мкм, температура колонки $30^{\circ} \mathrm{C}$; объем вводимой пробы составлял 10 мкл; скорость потока 0,3 мл/мин.

Условия масс-детектирования: тип ионизации - DUIS (ESI + APCI); режим - Product ion mode в положительной полярности; $\mathrm{Q}_{1}$ в $\mathrm{SIM}$ режиме при $\mathrm{m} / \mathrm{z}=876,1$; энергия ионизации в калюзионной ячейке $35 \mathrm{~B} ; \mathrm{Q}_{3}$ в режиме SCAN с диапазоном $\mathrm{m} / \mathrm{z}$ от 123,2-876,1. Для количественного определения белка Bet v 1 использовался метод абсолютной калибровки.

\section{Обсуждение результатов}

В ходе эксперимента проведена валидация методики по показателям селективность, прецизионность, точность, линейность, предел обнаружения и предел определения.

Идентификация мажорного белка Bet v 1 проводилась по основному иону 876,1 и по характерной фрагментации этого иона. При масс-детектировании происходит дробление молекулы белка на фрагменты с уникальной массой (система ионизации DUIS: ESI+APCI, $\mathrm{Q}_{3}$ в режиме SCAN с диапазоном $\mathrm{m} / \mathrm{z}$ от $123,2-$ $876,1)$, регистрирование которых позволяет четко определять исходное соединение, поскольку схема фрагментации индивидуальна у каждой белковой структуры.

В результате была разработана чувствительная и селективная методика количественного определения белка Bet v 1, которая может быть использована для стандартизации экстрактов пыльцы березы, применяемых при проведении АСИТ.

\section{Выводы}

Проведенные исследования позволили нам разработать универсальную методику ВЭЖХ/MC/MC количественного содержания мажорного белка Bet v 1 в экстракте пыльцы березы. Результаты проведенной валидации подтверждают то, что разработанная методика пригодна для контроля качества экстракта пыльцы березы и может быть включена в соответствующую фармакопейную статью. 


\section{Список литературы}

1. Куцик Р.В., Зузук Б.М. Береза повислая Betula pendula Roth. (Betulaceae). Аналитический обзор // Провизор. 2001. №10. [Электронный ресурc]: URL: http://www.provisor.com.ua/archive/2001/N10/art_17.php (дата обращения: 18.07.2013).

2. Первышина Г.Г., Ефремов А.А., Гордиенко Г.П., Агафонова Е.А., Губанова И.С., Гоголева О.В. К вопросу комплексного изучения березы повислой (Betula pendula Roth.), произрастающей в Красноярском крае // Химия растительного сырья. 2002. №3. С. 17-20.

3. Боков Д.О. Разработка подходов к стандартизации и методов контроля качества аллергенных экстрактов, применяемых при проведении аллерген-специфической иммунотерапии (АСИТ) // Медицинская весна: материалы Всеросс. студ. науч. конф. с междунар. участием. М., 2013. С. 214-216.

4. Ведерников Д.Н., Рощин В.И. Экстрактивные вещества листьев березы повислой Betula pendula Roth. (Betulaceae). 1. Групповой состав, состав летучих соединений и кислот эфирных экстрактов // Химия растительного сырья. 2012. №1. С. 93-100.

5. Демина Л.Н., Паршикова В.Н., Степень Р.А. Минеральный состав водных экстрактов листьев Betula pendula Roth., Ribes nigrum L. // Химия растительного сырья. 2003. №4. С. 57-60.

6. Сосипатрова А.А., Осипов В.И., Демина Н.Б., Быков В.А. Биологически активные вещества сухого экстракта листьев березы: идентификация и количественное определение соединений нефенольной природы методом ГХ-МС // Вопросы биологической, медицинской и фармацевтической химии. 2011. №7. С. 15-23.

7. Ведерников Д.Н., Рощин В.И. Экстрактивные вещества почек березы повислой Betula pendula Roth. (Betulaceae). 1. Состав жирных кислот, углеводородов и сложных эфиров // Химия растительного сырья. 2009. №3. C. 69-74.

8. Ведерников Д.Н., Рощин В.И. Экстрактивные вещества почек березы повислой Betula pendula Roth. (Betulaceae). 2. Карбонильные соединения и оксиды. сложные эфиры // Химия растительного сырья. 2009. №3. C. 75-84.

9. Ведерников Д.Н., Рощин В.И. Экстрактивные вещества почек березы повислой Betula pendula Roth. (Betulaceae). 3. Состав тритерпеновых кислот, флавоноидов, спиртов и эфиров // Химия растительного сырья. 2010. №4. С. 67-75.

10. Ведерников Д.Н., Рощин В.И. Экстрактивные вещества почек березы повислой Betula pendula Roth. (Betulaceae). 4. Состав сесквитерпеновых диолов, триолов, флавоноидов // Химия растительного сырья. 2011. №1. С. 111-118.

11. Ведерников Д.Н., Рощин В.И. Экстрактивные вещества почек березы повислой Betula pendula Roth. (Betulaceae). 5. Состав тритерпеновых секо-кислот // Химия растительного сырья. 2011. №3. С. 95-102.

12. Куркин В.А. Лекарственные растения как источник импортозамещающих препаратов // Фундаментальные исследования. 2013. №8-1. С. 139-142.

13. Ветчинникова Л.В., Серебрякова О.С., Ильинова М.К. Жирнокислотный состав липидов пыльцы основных представителей рода Betula L. // Труды Карельского научного центра РАН. 2012. №2. C. 56-62.

14. Дёмин М.С., Осипов В.И., Демина Н.Б., Быков В.А. Состав метаболитов липофильной фракции плодов ноготков лекарственных // Вопросы биологической, медицинской и фармацевтической химии. 2010. №3. С. 32-35.

15. Желтикова Т.М. Аллергены для аллерген-специфической иммунотерапии: достижения и проблемы // Consilium medicum. Педиатрия. 2012. №1. С. 29-31.

16. Астафьева Н.Г., Перфилова И.А., Удовиченко Е.Н., Гамова И.В., Гапон М.С., Кенесариева Ж.М. Фармакоэпидемиология пыльцевого аллергического ринита // Бюллетень медицинских Интернет-конференций. 2012. T. 2, №3. C. 55-61.

17. Шамгунова Б.А., Заклякова Л.В. Аэропалинологические аспекты поллинозов // Астраханский медицинский журнал. 2010. №1. С. 27-35.

18. Передкова Е.В. Пыльцевая аллергия // Consilium medicum (Оториноларингология). 2009. №3. С. $63-66$.

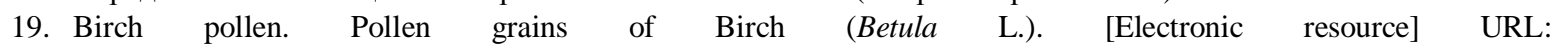
http://www.vcbio.science.ru.nl/images/pollen/pollen17.jpg (Date accessed: 03.07.2013).

20. Ахапкина И.Г. Актуальность использования иммуноферментного анализа для характеристики аллергенной нагрузки жилых помещений // Пест-менеджмент = Pest-management. 2011. №4. C. 13-17.

21. European pharmacopoeia. $7^{\text {th }}$ ed. suppl. 7.0 Strasbourg: European Department for the Quality of Medicines. 2010. Vol. 1. 1207 p.

22. Павлов А.Е. Сейлиева Н.А., Мухортых О.Ю. Получение и оценка свойств рекомбинантного аналога мажорного аллергена пыльцы березы Bet v 1 // Российский аллергологический журнал. 2012. №3. С. 7-13.

23. Определение специфических IgG к аллергенам пыльцы березы. №6620 Береза, пыльца, IgG (Birch Pollen, Betula, IgG, T3). [Электронный ресурс]. URL: http://www.invitro.ru/analizes/for-doctors/138/6925/ (дата обращения: 10.07.2013)

24. Coca A.F. Studies in Specific Hypersensitiveness: V. The Preparation of Fluid Extracts and Solutions for Use in the Diagnosis and Treatment of the Allergies with Notes on the Collection of Pollens // J. Immunol. 1922. Vol. 7, N2. Pp. 163-178. 
Bokov D.O., Smirnov V.V. ALLERGENIC PROFILE OF BIRCH POLLEN (BETULA PENDULA ROTH) FULL EXTRACT: STUDY OF IDENTIFICATION AND QUANTIFICATION METHODOLOGICAL PROCEDURES FOR BETV1 MAJOR PROTEIN BY LC-MS

I.M. Sechenov First Moscow State Medical University, Trubetskaia st., 8, Moscow, 119991, (Russia),

e-mail:fmmsu@mail.ru

Since ancient times, silver birch, Betula pendula Roth (Betulaceae L.), is used in medicine practice, thanks to a wide range of bioactive compounds presented in almost all parts of the plant. However, birch pollen is the cause of severe allergic diseases - hay fever. The report provides data concerning the standardization of the full birch pollen allergen extract composition. This biological product is the sum of allergenic proteins (Betv), is used for allergen-specific immunotherapy (SIT). Since the Russian standardization protocols of the allergen extract did not meet the requirements of the modern world, it had become necessary to develop a sensitive method for the quantitative determination of the main allergenic protein Betv1 using modern physical and chemical methods, such as LC-MS.

Keywords: silver birch, Betula pendula Roth., Betula verrucosa Ehrh., pollen, allergenic extract, Betv1, allergenspecific immunotherapy (SIT), hay fever, LC-MS

\section{References}

1. Kutsik R.V., Zuzuk B.M. Provizor, 2001, no. 10. [Electronic resource]. URL:. http://www.provisor.com.ua/archive/ 2001/N10/art_17.php (in Russ.).

2. Pervyshina G.G., Efremov A.A., Gordienko G.P., Agafonova E.A., Gubanova I.S., Gogoleva O.V. Khimiia rastitel'nogo syr'ia, 2002, no. 3, pp. 17-20. (in Russ.).

3. Bokov D.O. Meditsinskaia vesna: sb. materialov Vseross. stud. nauch. konf. s mezhdunar. uchastiem. [Medical spring: All-Russian Student Conference with international participation]. Moscow, 2013, pp. 214-216. (in Russ.).

4. Vedernikov D.N., Roshchin V.I. Khimiia rastitel'nogo syr'ia, 2012, no. 1, pp. 93-100. (in Russ.).

5. Demina L.N., Parshikova V.N., Stepen' R.A. Khimiia rastitel'nogo syria, 2003, no. 4, pp. 57-60. (in Russ.).

6. Sosipatrova A.A., Osipov V.I., Demina N.B., Bykov V.A. Voprosy biologicheskoi, meditsinskoi i farmatsev-ticheskoi khimii, 2011, no. 7, pp. 15-23. (in Russ.).

7. Vedernikov D.N., Roshchin V.I. Khimiia rastitel'nogo syr'ia, 2009, no. 3, pp. 69-74. (in Russ.).

8. Vedernikov D.N., Roshchin V.I. Khimiia rastitel'nogo syr'ia, 2009, no. 3, pp. 75-84. (in Russ.).

9. Vedernikov D.N., Roshchin V.I. Khimiia rastitel'nogo syr'ia, 2010, no. 4, pp. 67-75. (in Russ.).

10. Vedernikov D.N., Roshchin V.I. Khimiia rastitel'nogo syr'ia, 2011, no. 1, pp. 111-118. (in Russ.).

11. Vedernikov D.N., Roshchin V.I. Khimiia rastitel'nogo syr'ia, 2011, no. 3, pp. 95-102. (in Russ.).

12. Kurkin V.A. Fundamental'nye issledovaniia, 2013, no. 8-1, pp. 139-142. (in Russ.).

13. Vetchinnikova L.V., Serebriakova O.S., Il'inova M.K. Trudy Karel'skogo nauchnogo tsentra RAN, 2012, no. 2, pp. 56-62. (in Russ.).

14. Demin M.S., Osipov V.I., Demina N.B., Bykov V.A. Voprosy biologicheskoi, meditsinskoi i farmatsevticheskoi khimii, 2010, no. 3, pp. 32-35. (in Russ.).

15. Zheltikova T.M. Consilium medicum. Pediatriia, 2012, no. 1, pp. 29-31. (in Russ.).

16. Astaf'eva N.G., Perfilova I.A., Udovichenko E.N., Gamova I.V., Gapon M.S., Kenesarieva Zh.M. Biulleten' meditsinskikh Internet-konferentsii, 2012, vol. 2, no. 3, pp. 55-61. (in Russ.).

17. Shamgunova B.A., Zakliakova L.V. Astrakhanskii meditsinskii zhurnal, 2010, no. 1, pp. 27-35. (in Russ.).

18. Peredkova E.V. Consilium medicum (Otorinolaringologiia), 2009, no. 3, pp. 63-66. (in Russ.).

19. Birch pollen [Electronic resource]. Pollen grains of Birch (Betula L.). Access mode: URL: http://www.vcbio.science.ru.nl/images/pollen/pollen17.jpg.

20. Akhapkina I.G. Pest-menedzhment = Pest-management, 2011, no. 4, pp. 13-17. (in Russ.).

21. European pharmacopoeia. $7^{\text {th }}$ ed. suppl. 7.0 Strasbourg: European Department for the Quality of Medicines. 2010. Vol. 1. 1207 p.

22. Pavlov A.E. Seilieva N.A., Mukhortykh O.Iu. Rossiiskii allergologicheskii zhurnal, 2012, no. 3, pp. 7-13. (in Russ.).

23. Opredelenie spetsificheskikh IgG k allergenam pyl'tsy berezy: №6620 Bereza, pyl'tsa, IgG (Birch Pollen, Betula, IgG, T3). [Detection of specific IgG antibodies to allergens of birch pollen: №6620 birch pollen, IgG (Birch Pollen, Betula, IgG, T3)]. [Electronic resource]. URL: http://www.invitro.ru/analizes/for-doctors/138/6925/.(in Russ.).

24. Coca A.F. J. Immunol., 1922, vol. 7, no. 2, pp. 163-178.

\footnotetext{
* Corresponding author.
} 